\title{
A two-pronged approach in leishmaniasis drug development in Kenya Medical Research Institute
}

\author{
Robert M. Karanja and Willy K. Tonui, \\ Centre for Biotechnology Research \& Development, Kenya Medical Research Institute,P.O. Box \\ 54840-00-200, Nairobi, Kenya
}

Neglected diseases such as leishmaniasis, trypanosomiasis, Chagas disease, and malaria have a devastating impact on the world's poor. Phlebotomine sand flies transmit leishmaniasis a protozoal disease found in arid and semi arid areas of Kenya. The two forms of the disease found in Kenya are cutaneous (induces lesions on the skin) and visceral (affect internal organs the spleen, liver and better known as kala azar) leishmaniasis. The disease has been reported in Baringo, Kitui, west Pokot and Turkana districts [1]. Baringo district is the only region in Kenya where both cutaneous and kala azar has been reported in Kenya. More recently kala azar has been reported in Kerio valley in North Baringo [2], East and West Pokot [3, 4], Wajir and Mandera districts [5].

The market driven dynamics of normal drug development no longer suffice for the control and treatment this disease [6]. Increased regulation in the pharmaceutical and health industry has led to mounting costs in drugs/vaccine development [7]. Consequently multinational pharmaceuticals, being the bestendowed parties in terms of human capacity and technical infrastructure, have inadvertently shunned the needs of the South [8]. Heightened awareness of these shortcomings in the traditionally Smithsonian laissez faire approach in drug development and increasing mobility of human populations has given impetus for novel paradigms of drug/vaccine development for neglected diseases such as leishmaniasis [7]. These include privatepublic-partnerships (PPPs) that seek to bring together the relative strengths of the public and private sectors, and to incubate the development of drugs/vaccines of major public health in the South $[9,10]$. One such PPP is the Drugs for Neglected Diseases initiative (DNDi), an international foundation whose founding partners include the Indian Council of Medicine Research, Médecins Sans
Frontières (MSF), and Kenya Medical Research Institute (KEMRI) among others [11].

KEMRI's Centre for Clinical Research (CCR) and Centre for Biotechnology Research \& Development (CBRD) brings to DNDi a rich history of involvement in tropical diseases and expertise in both clinical and biomedical research for neglected diseases. Over the last 25 years, scientists at CCR have been addressing the issue of treatment options for Kala-azar. Through collaborations with WHO and others, CCR has participated in the clinical studies of AmBisome ${ }^{\mathbb{B}}$ a safer and more effective lipid formulation of Amphotericin B (second line VL treatment), and more recently in the trials of Sitamaquine $^{\circledR}$, an oral drug developed by the Walter Reed Army Medical Research (WRAIR) and GlaxoSmithKline. A leader in innovation, CCR scientists have also been involved in determining the optimum effective dose for the treatment of VL using Sodium stibogluconate, and to shorten the duration of treatment from 30 to approx. 15 days [12] KEMRI has also participated in the testing of diagnosis techniques such as enzyme linked immunosorbent assays (ELISA) and direct agglutination test (DAT), that offer cheap, safer, non-invasive and more field adaptable alternatives to parasitological techniques [13, 14]. To capitalize on these strengths, DNDi's liaison office overseeing the clinical trials of Paramomycin (Aminosidine) is headquartered at CCR, KEMRI. These phase 3 multi-center trials are being coordinated through the leishmaniasis east African platform (LEAP) programme, and may very well result in a policy shift from Sodium stibogluconate to Paramomycin as the first line treatment for leishmaniasis in east Africa [15]. Similar trials are also being conducted in India under the 
aegis of the Institute of One World Health (IOWH), another PPP [11].

In the downstream end of drug development, a simple paradigm using an innovative approach rather than invention is being developed at CBRD's Leishmania laboratory. This is to "leap frog" drug development by screening registered compounds that are already in the market whose therapeutic indication can be expanded to include leishmaniasis. By taking advantage of an ever-increasing body of knowledge such as the recently completed Leishmania major genome, the development of new drugs for leishmaniasis can be carried "piggy-back" on the drug development efforts of other diseases such as malaria [6, 16]. Plasmodium falciparum (malaria parasite), a protozoan pathogen of major public health, is encompassed by the millennium development goals (MDGs) thus benefiting from increased media coverage to avail funds for drug and vaccine development. Moreover, malaria treatment benefits from a relatively larger arsenal of safe, effective, oral drugs that are relatively cheaper in comparison to those available for the treatment of leishmaniasis $[17,18]$. Many of these drugs, their derivatives and isomers, have previously been shown to have anti-leishmanial effects but with little fiscal incentive, their development against leishmaniasis has been neglected. Basic research underlying drug targets has shown considerable overlap of target pathways such as dihydrofolate reductase (DHFR)/thymidylate synthase and type II fatty acid synthesis that occurs in Plasmodium and Leishmania, but not in humans [19, 20].

Studies at CBRD, KEMRI have already demonstrated the potential of orally administered artemisinin in clearing $L$. major infection in mice [21]. Artemisinin based combined therapy (ACT) has slowly emerged as the way forward for treatment of malaria in light of widespread resistance to existing drugs, with WHO recommended Coartem ${ }^{\mathbb{B}}$ (artemether + lumenfantrine) recently being co-opted into the national strategy as the first line drug of treatment for malaria [22]. The chemotherapeutic switch of other malarial drugs such as Sulfadoxine-Pyrimethamine (SP) whose pyrimethamine component targets the folate synthesis pathway in Plasmodium can salvage such cheap and easily accessible drugs that have otherwise been rendered useless due to widespread resistance. By developing drugs for Leishmania on the back of other drug development efforts, safe, oral drugs can be thus be availed for treatment of leishmaniasis with minimum expenditure of money and time. In this way KEMRI is taking a two-pronged approach towards availing new drugs for leishmaniasis by collaborating with international partners through PPPs in upstream drug development, and by evolving an innovative "leap frog" approach in downstream drug development for leishmaniasis. Both are aimed at availing safer, effective drugs for a most neglected disease, while maximizing expertise and efficiency. KEMRI has also initiated studies aimed at testing extracts/compounds from medicinal plants used widely by the local people for treating splenomegaly related ailments in Leishmania endemic areas of Kenya. Knowledge obtained is relayed back to the community. Through these efforts KEMRI has identified some plants that have antileishmanial properties.

\section{References}

1. Fendall NR. The spread of kala-azar in Kenya. East African Medical Journal 1961; 38: 417-419.

2. Mbui J; Rashid R; Lodenyo H; Nyakundi P; Kipmutai R; Mutuma G; Kirigi G; Kinoti D and Wasunna M. Visceral leishmaniasis with concomitant post kalaazar dermal leishmaniasis responds to oral sitamaquine: case report. East African Medical Journal. 2003; 80:440-2.

3. Mutero CM; Mutinga MJ; Ngindu AM; Kenya PR and Amimo FA. Visceral leishmaniasis and malaria prevalence in West Pokot District, Kenya. East African Medical Journal. 1992; 69:3-8.

4. Moore E; O'Flaherty D; Heuvelmans H; Seaman J; Veeken $\mathrm{H}$; de Wit $\mathrm{S}$ and Davidson RN. Comparison of generic and proprietary sodium stibogluconate for the treatment of visceral leishmaniasis in Kenya. Bulletin of the World Health Organization. 2001; 79:388-93.

5. Marlet MV; Sang DK; Ritmeijer, K; Muga $\mathrm{RO}$; Onsongo $\mathrm{J}$ and Davidson $\mathrm{RN}$. Emergence or re-emergence of visceral 
leishmaniasis in areas of Somalia, northeastern Kenya and south-eastern Ethiopia in 2000-01. Transactions of the Royal Society for Tropical Medicine Hygiene. 2003; 97: 515-8.

6. Croft SL and Coombs GH. Leishmaniasis-current chemotherapy and recent advances in the search for novel drugs. Trends in Parasitology. 2003;19:502-8.

7. Croft SL. Public-private partnership: from there to here. Transactions of the Royal Society for Tropical Medicine and Hygiene. 2005; 99 Suppl 1: 9-14.

8. Trouiller P; Olliaro P; Torreele E; Orbinski J; Laing $\mathrm{R}$ and Ford N. Drug development for neglected diseases: a deficient market and a public-health policy failure. Lancet. 2002; 359: 2188-94.

9. Nwaka S and Ridley RG. Virtual drug discovery and development for neglected diseases through public-private partnerships. Nature Reviews on Drug Discovery. 2003; 2: 919-928.

10. Morel CM; Acharya T; Broun D; Dangi A; Elias C; Ganguly NK; Gardner CA; Gupta RK; Haycock J; Heher AD; Hotez PJ; Kettler HE; Keusch GT; Krattiger AF; Kreutz FT; Lall S; Lee K; Mahoney R; Martinez-Palomo A; Mashelkar RA; Matlin SA; Mzimba M; Oehler J; Ridley RG; Senanayake P; Singer P and Yun M. Health innovation networks to help developing countries address neglected diseases. Science. 2005; 309: 401-4.

11. About DNDi. DNDi Web site: http://www.dndi.org/

12. Chulay JD; Bhatt SM; Muigai R; Ho M; Gachihi G; Were JB; Chunge $\mathrm{C}$ and Bryceson ADA. comparison of three dosage regimens of sodium stibogluconate in the treatment of visceral leishmaniasis in Kenya. Journal of Infectious Disease. 1983; 148: 148-55.

13. Harith AE;Kolk AH; Kager PA; Leeuwenburg J; Muigai R; Kiugu S; Kiugu S; Laarman JJ. A simple and economical direct agglutination test for serodiagnosis and sero-epidemiological studies of visceral leishmaniasis. Transactions of the Royal Society for Tropical Medicine and Hygiene. 1986; 80:583-36.
14. Mbati PA; Githure JI; Kagai JM; Kirigi G; Kibati F; Wasunna $\mathrm{K}$ and Koech DK. Evaluation of a standardized direct agglutination test (DAT) for the diagnosis of visceral leishmaniasis in Kenya. Annals of Tropical Medicine and Parasitology. 1999; 93:703-10.

15. Hailu A. LEAP: An east African collaboration on clinical trial of Paromomycin for VL. Symposium on Drugs for neglected diseases initiative. $25^{\text {th }}$ African health sciences congress, October 4-8 2004, Nairobi, Kenya.

16. Ivens $\mathrm{AC}$; Peacock CS; Worthey EA; Murphy L; Aggarwal G; Berriman M; Sisk E; Rajandream MA; Adlem E; Aert R; Anupama A; Apostolou Z; Attipoe P; Bason N; Bauser C; Beck A; Beverley SM; Bianchettin G; Borzym K; Bothe G; Bruschi CV; Collins M; Cadag E; Ciarloni L; Clayton C; Coulson RM; Cronin A; Cruz AK; Davies RM; De Gaudenzi J; Dobson DE; Duesterhoeft A; Fazelina G; Fosker N; Frasch AC; Fraser A; Fuchs M; Gabel C; Goble A; Goffeau A; Harris D; Hertz-Fowler C; Hilbert H; Horn D; Huang Y; Klages S; Knights A; Kube M; Larke N; Litvin L; Lord A; Louie T; Marra M; Masuy D; Matthews K; Michaeli S; Mottram JC; Muller-Auer S; Munden $\mathrm{H}$; Nelson $\mathrm{S}$; Norbertczak $\mathrm{H}$; Oliver K; O'neil S; Pentony M; Pohl TM; Price C; Purnelle B; Quail MA; Rabbinowitsch E; Reinhardt R; Rieger M; Rinta J; Robben J; Robertson L; Ruiz JC; Rutter S; Saunders D; Schafer M; Schein J; Schwartz DC; Seeger K; Seyler A; Sharp S; Shin H; Sivam D; Squares R; Squares S; Tosato V; Vogt C; Volckaert G; Wambutt R; Warren $\mathrm{T}$; Wedler $\mathrm{H}$; Woodward J; Zhou S; Zimmermann W; Smith DF; Blackwell JM; Stuart KD; Barrell B and Myler PJ. The genome of the kinetoplastid parasite, Leishmania major. Science. 2005; 309: 436-42.

17. Croft SL and Yardly V. Chemotherapy of Leishmaniasis. Current Pharmaceutical Design. 2002; 8:319-42.

18. Kumar A; Katiyar SB; Agarwal A and Chauhan PMS. Perspective in Antimalarial Chemotherapy. Current Medicinal Chemistry. 2003; 10:1137-50. 
19. Rondriques Coura J and de Castro SLA Critical Review on Chagas Disease Chemotherapy. Memórias do Instituto Oswaldo Cruz. 2002; 97:3-24.

20. Dennis M; Rono M. and Tonui W. Use of Dihydroartemisinin both for oral and topical treatment against Leishmania major in $\mathrm{BALB} / \mathrm{c}$ mice (un published)

21. Mutabingwa TK. Artemisinin-based combination therapies (ACTs): Best hope for malaria treatment but inaccessible to the needy! Acta Tropica. 2005; 95:305-15.

22. Roberts CW; McLeod R; Rice DW; Ginger M; Chance ML and Goad LJ. Fatty acid and sterol metabolism: potential antimicrobial targets in apicomplexan and trypanosomatid parasitic protozoa. Molecular Biochemistry and Parasitology. 2003; 126:129-142. 